\title{
Crop Diversification in Rangpur Region
}

\author{
M A U Zaman ${ }^{1 *}$, S Pramanik², N Parvin ${ }^{1}$ and A Khatun ${ }^{1}$
}

\begin{abstract}
For the planning of future research and development elaborate information and a reliable database on existing cropping patterns, cropping intensity and crop diversity of a particular area are of prime importance for guiding policy makers, researchers, extensionists and development workers. A massive group work was accomplished over all 35 upazilas of Rangpur region during 2016 using pre-tested semistructured questionnaire with a view to document the existing cropping patterns, cropping intensity and crop diversity in the area. Boro-Fallow-T. Aman occupied the largest portion (53\%) of net cropped area (NCA) with its distribution in all upazilas. The second largest area, $5 \%$ of NCA, was covered by Maize-Fallow-T. Aman which was spread out over 23 upazilas. Under the current investigation 134 cropping patterns were identified. The highest number of cropping patterns was identified 31 in Badarganj of Rangpur and the lowest was 10 in Razibpur of Kurigram district. The highest value of CDI was observed 0.991 in Razibpur upazila followed by 0.989 in Chilmari of Kurigram. The range of cropping intensity values was recorded $190-255 \%$. The maximum value was for Gangachara upazila of Rangpur and minimum for Gaibandha sadar upazila. The overall CDI of Rangpur region was calculated 0.871 and the average cropping intensity at regional level was $219 \%$.
\end{abstract}

Key words: Cropping system, tobacco, land use, diversity index and Jamuna Floodplain

\section{INTRODUCTION}

Five districts namely Rangpur, Gaibandha, Nilphamari, Lalmonirhat and Kurigram are included in Rangpur region. It belongs to mainly Tista Meander Floodplain (AEZ-3) and also to North-eastern Barind Tract (AEZ-27), Active Tista Floodplain (AEZ-2), Active BrahmaputraJamuna Floodplain (AEZ-7) and Young Brahmaputra and Jamuna Floodplains (AEZ8 ). In this region some areas are susceptible to flooding when the Jamuna river overflows its banks leaving local communities without land, housing and sanitation, or any assets to make normal living to continue. Extreme weather events are already affecting crop production and water resources in this region. The region has been facing the early impact of climate change. These changes have already creates major impacts on the livelihoods of the large number of poor people. It has reduced fresh water availability, increased drought, floods, and natural disaster in different forms.
Cropping system is the crop production activity of a farm, which includes all cropping patterns grown on the farm resources, other household enterprises and the physical, biological, technological and socioeconomic factors or environments. A cropping pattern is the yearly sequence, temporal and spatial arrangement of crops in a given land area. It is dependent on physical, historical, social, institutional and economic factors as well as government policies (Agrawal and Kassam, 1976). The cropping pattern and the changes therein depend on a large number of factors like climate, soil type, rainfall, agricultural technology, availability of irrigation facilities and other inputs, marketing and transport facilities and growth of agro-industries (Neena, 1998; Gadge 2003; Rashid et al., 2005). Diversified cropping pattern may be an option for the farmers as a coping strategy against risks (Mandal and Bezbaruah, 2013). Typology of different cropping systems is the base for the managers of these systems to intensify

${ }^{1}$ Rice Farming Systems Division, BRRI, Gazipur; ${ }^{2}$ BRRI RS Rangpur; *Corresponding author's E-mail: asad.brri@gmail.com 
production (Shriar, 2000). There is a strong need for judicious and appropriate use limited resources in case of intervention selection that does not lead to increased mal adaption or inequity in the society over long term. Existing trend of available agricultural lands are most essential requirement for any land use planning related to farming and food security in a sustainable manner. Therefore, an increased understanding of arable land use based on the cropping system is essential for the appropriate intervention in sustainable way. In these context, existing cropping patterns along with their diversity of such complex agricultural region are very crucial for risk minimization and overall productivity improvement. The present study was designed with the following specific objectives to:

- $\quad$ understand the existing cropping patterns scenario in Rangpur region

- $\quad$ visualize the existing land use pattern at upazila and regional level

- determine the crop diversity and cropping intensity at local and regional level.

\section{METHODOLOGY}

Thirty-five upazilas of Rangpur, Gaibandha, Nilphamari, Lalmonirhat and Kurigram were the location of this study. Data were collected using double stage procedure. At initial stage, data were collected through pre-tested semi-structured questionnaire from 35 preassigned Sub-Assistant Agriculture Officers (SAAO) of each upazila during June 2016 at upazila level. SAAOs were purposively preselected by Agriculture Extension Officers (AEO), Additional Agriculture Officer (AAO) and Upazila Agriculture Officer (UAO) or altogether. Prior to data collection, the pretested questionnaire was explained along with proper guidelines to the AEOs or UAOs or both and handed over to them at each Deputy Director's office of the Directorate of Agricultural Extension (DAE) during monthly meeting for the sake of accurate data collection.
The scientists of RFS Division collected The filled questionnaires, checked and analyzed those find the inconsistencies of the supplied data before validation workshop. All the inconsistencies among the information were documented. The collected data along with documented inconsistencies were discussed in district level workshop to for necessary correction and validation. Second stage of data collection was day-long data validation workshop at district level. The workshop dates were 30 August for Kurigram; 31 August for Rangpur; 19 September for Lalmonirhat; 21 September for Gaibandha; and 5 October 2016 for Nilphamari. Four field-workers i e one SAPPO and three SAAOs experienced and engaged in crop-based data documentation, all officers from all upazilas viz UAOs, AEOs, AAEOs, DD (DAE), DD (Horticulture), DD of Seed Certification Agency, DTO and ADDs, one representative from Agricultural Training Institute (ATI) and scientists of BRRI regional station, Rangpur participated in the data validation workshop. The number of participants of validation workshop ranged from 48 to 84 in each district. All the participants were divided into three to four groups for data validation. Each group was facilitated by two RFSD scientists to finalize and validate the data and authenticated data were captured. Crop diversity index was calculated by using the following equation described by Kshirsagar et al. (1997).

$$
C D I_{i}=1-\sum_{j=o}^{n}\left(\frac{a_{i j}}{A_{i}}\right)^{2}
$$

Where, $\mathrm{CDI}_{\mathrm{i}}=$ Crop Diversity Index $a_{i j}=$ Area planted to the $j^{\text {th }}$ crop in the $i^{\text {th }}$ location

$A_{i}=$ Total area planted under all crops

The index is zero for a land area growing only one crop. It approaches unity as the level of diversity increases. Compilation and processing of collected data were done using Micro Soft Excel programme. Descriptive statistics were used to facilitate the presentation of the findings. 
RESULTS AND DISCUSSION

\section{Land use}

Table 1 lists status of agricultural land utilization. The net cropped area of the Rangpur region is 696,420 ha. Crops occupying the particular land for round the year were considered under annual crops. The major annual crops reported in the region were pineapple, sugarcane, banana, papaya, betel leaf, ginger and turmeric. The annual crops area in different upazilas ranged from 20 to 2,610 ha. The annual crops area accounted only $2 \%$ of the net cropped area (NCA) in the region. At a glance the region possesses about $6 \%$ single cropped area (SCA), 64\% double cropped area (DCA), $27 \%$ triple cropped area (TCA). The quadruple cropped area (QCA) also exists as a very negligible portion $(0.03 \%)$ and is limited in only two upazilas viz Gangachara and Rowmari. The SCA had the major share of NCA in Pirganj upazilas of Rangpur district; Chilmari and Nagesawari of Kurigram district; Sundarganj, Fulchhari and sadar upazila of Gaibandha district followed by corresponding double cropped area (DCA). Pirgachha upazila of Rangpur district, Palasbari of Gaibandha, Saidpur and Dimla of Nilphamari had no single cropped area at all. Most of the upazilas were dominated by DCA. The exceptions are Gangachara upazila of Rangpur district where triple cropped area is the dominating one (Table 1). The area, which could not be defined under SCA, DCA, TCA or QCA was considered as other whose coverage is less than $1 \%$ of the NCA.

\section{Cropping patterns of Rangpur}

In total 134 cropping patterns were observed in Rangpur region of which five cropping patterns with exclusive rice crop covers over $58 \%$ of the NCA. There were 49 cropping patterns with exclusive non-rice crop covering over $6 \%$ of the NCA. Rest of the NCA ie about $36 \%$ area is covered by 80 rice - non rice cropping patterns (Appendix 1).

\section{Rice and non-rice crops at a glance}

Rice is the only crop round the year in five cropping patterns (Table 2). It comprises
$58.32 \%$ of the NCA in the region. Among them single rice and double rice represent around $4.12 \%$ and $54.20 \%$ respectively. There is no triple rice area in Rangpur region. It reflects the unparallel dominance of rice in the cropping systems in Rangpur region. In case of individual pattern Boro-Fallow-T. Aman has the highest coverage $(53.33 \%)$ and was recorded in all 35 upazilas. The second dominant pattern single Boro area occupied $4.07 \%$ of NCA which was reported in 28 upazilas. Single T. Aman covered $0.05 \%$ area with its existence in Rangpur sadar upazila only.

In the current investigation, 49 cropping patterns were identified that was free from rice. Among them, first 30 have been arranged in descending order (Table 3 ). The rest 19 patterns with negligible area coverage are arranged in Table 8 with other patterns of different categories. Aggregate of the 49 patterns have had $6.41 \%$ of NCA. In critical comparison is clear that exclusive rice area is about nine folds of exclusive non-rice area. In Rangpur region crop diversity is much wider than that of other regions like Sylhet and Chittagong where exclusive rice area covers 37 folds and 23 fold, respectively, of exclusive non-rice area (Muttaleb et al., 2017; Shahidullah et al., 2017). Appropriate cropping patterns may facilitate maximum possible land utilization as well as efficient use of other scarce resources in a sustainable manner. Diversified cropping pattern may be an option for the farmers as a cropping strategy against risks (Mandal and Bezbaruah, 2013). Typology of different cropping systems is the base for the managers of these systems to intensify production (Shriar, 2000).

\section{Non-rice cereal crops}

Thirty-five cropping patterns holding different non-rice cereal crops viz maize, wheat, millets (cheena and kaon) (Table 4) which in-together covered $15.82 \%$ of NCA. Among them two cropping patterns viz Maize-Fallow-T. Aman and Wheat-Jute-T. Aman jointly occupied $8.65 \%$ of NCA. Maize is covering the largest 
Table 1. Land use of different upazilas in Rangpur region (area in hectare), 2014-15.

\begin{tabular}{|c|c|c|c|c|c|c|c|c|c|c|}
\hline & Upazila & $\begin{array}{l}\text { Area of } \\
\text { upazila }\end{array}$ & $\begin{array}{l}\text { Annual } \\
\text { crop }\end{array}$ & SCA & DCA & TCA & QCA & Other & NCA & C.I. (\%) \\
\hline 01 & Rangpur & 13981 & 190 & 470 & 7510 & 3250 & 0 & 170 & 11590 & 223 \\
\hline 02 & Gangachara & 24574 & 140 & 500 & 8150 & 11720 & 200 & 130 & 20840 & 255 \\
\hline 03 & Kaunia & 14757 & 200 & 600 & 5620 & 5460 & 0 & 120 & 12000 & 239 \\
\hline 04 & Pirgachha & 26518 & 630 & 0 & 13580 & 5500 & 0 & 120 & 19830 & 225 \\
\hline 05 & Pirganj & 40932 & 940 & 5390 & 19000 & 7200 & 0 & 110 & 32640 & 203 \\
\hline 06 & Badarganj & 30127 & 900 & 350 & 14010 & 6880 & 0 & 160 & 22300 & 225 \\
\hline 07 & Mithapukur & 51584 & 630 & 1510 & 26320 & 15950 & 0 & 120 & 44530 & 231 \\
\hline 08 & Taraganj & 12866 & 720 & 150 & 7300 & 3180 & 0 & 170 & 11520 & 220 \\
\hline 09 & Gaiba. sadar & 32024 & 30 & 3340 & 14650 & 1360 & 0 & 150 & 19530 & 190 \\
\hline 10 & Palasbari & 18525 & 500 & 0 & 11670 & 1950 & 0 & 130 & 14250 & 210 \\
\hline 11 & Gobindaganj & 46003 & 2610 & 1740 & 20100 & 11780 & 0 & 180 & 36410 & 221 \\
\hline 12 & Saghata & 23109 & 100 & 1080 & 11350 & 4220 & 0 & 150 & 16900 & 218 \\
\hline 13 & Fulchhari & 30654 & 20 & 2270 & 11370 & 2320 & 0 & 140 & 16120 & 200 \\
\hline 14 & Sundarganj & 41214 & 270 & 2090 & 23550 & 4950 & 0 & 110 & 30970 & 208 \\
\hline 15 & Sadullapur & 22800 & 580 & 20 & 13290 & 3100 & 0 & 190 & 17180 & 215 \\
\hline 16 & Kurigram & 26566 & 500 & 900 & 11140 & 6370 & 0 & 190 & 19100 & 226 \\
\hline 17 & Ulipur & 45867 & 60 & 1450 & 17510 & 5090 & 0 & 150 & 24260 & 215 \\
\hline 18 & Chilmari & 22998 & 50 & 3500 & 5750 & 2500 & 0 & 150 & 11950 & 191 \\
\hline 19 & Rowmari & 19200 & 190 & 140 & 7630 & 5900 & 10 & 120 & 13990 & 240 \\
\hline 20 & Razibpur & 11303 & 240 & 1750 & 4140 & 2480 & 0 & 130 & 8740 & 206 \\
\hline 21 & Bhurungamari & 22800 & 220 & 1230 & 11190 & 4640 & 0 & 140 & 17420 & 218 \\
\hline 22 & Nageswari & 42080 & 160 & 4000 & 19265 & 4275 & 0 & 160 & 27860 & 200 \\
\hline 23 & Phulbari & 15658 & 250 & 50 & 9500 & 2600 & 0 & 150 & 12550 & 219 \\
\hline 24 & Rajarhat & 16622 & 90 & 1010 & 9630 & 2610 & 0 & 150 & 13490 & 211 \\
\hline 25 & Nilphamari & 37308 & 140 & 1200 & 18230 & 10510 & 0 & 160 & 30240 & 230 \\
\hline 26 & Saidpur & 12167 & 160 & 0 & 7360 & 1420 & 0 & 120 & 9060 & 214 \\
\hline 27 & Domar & 25084 & 310 & 150 & 14540 & 4920 & 0 & 140 & 20060 & 222 \\
\hline 28 & Dimla & 32688 & 640 & 1050 & 16710 & 4940 & 0 & 100 & 23440 & 214 \\
\hline 29 & Jaldhaka & 33675 & 540 & 0 & 16990 & 6030 & 0 & 130 & 23690 & 223 \\
\hline 30 & Kishoreganj & 20502 & 520 & 250 & 7510 & 6690 & 0 & 150 & 15120 & 240 \\
\hline 31 & Lalmonirhat & 26075 & 500 & 500 & 11300 & 6820 & 0 & 180 & 19300 & 230 \\
\hline 32 & Aditmari & 19503 & 280 & 1090 & 8520 & 6115 & 0 & 125 & 16130 & 230 \\
\hline 33 & Kaliganj & 23694 & 170 & 250 & 15040 & 3860 & 0 & 150 & 19470 & 218 \\
\hline 34 & Hatibandha & 28777 & 230 & 1050 & 15820 & 5770 & 0 & 160 & 23030 & 220 \\
\hline 35 & Patgram & 26151 & 110 & 200 & 16060 & 4390 & 0 & 150 & 20910 & 220 \\
\hline \multicolumn{3}{|c|}{ Rangpur region } & 13820 & 39280 & 451305 & 186750 & 210 & 5055 & 696420 & 219 \\
\hline
\end{tabular}

Table 2. Cropping patterns with exclusive rice in Rangpur region, 2014-15.

\begin{tabular}{llrrc}
\hline & Cropping pattern & Area (ha) & \% of NCA & Frequency (no. of upazila) \\
\hline 01 & Boro-Fallow-T. Aman & 371370 & 53.33 & 35 \\
02 & Boro-Fallow-Fallow & 28320 & 4.07 & 28 \\
03 & Boro-Aus-T. Aman & 5640 & 0.81 & 13 \\
04 & Fallow-Fallow-T. Aman & 350 & 0.05 & 1 \\
05 & Boro-Sesbania-T. Aman & 480 & 0.07 & 3 \\
\hline & Total & 406160 & 58.32 & \\
\hline
\end{tabular}


Table 3. Cropping patterns with exclusivenon-rice in Rangpur region, 2014-15.

\begin{tabular}{|c|c|c|c|c|}
\hline & Cropping pattern & Area (ha) & $\%$ of NCA & Frequency (no. of upazila) \\
\hline 01 & Vegetab-Vegetab-Vegetab & 10590 & 1.52 & 25 \\
\hline 02 & Vegetab-Vegetab-Fallow & 4670 & 0.67 & 11 \\
\hline 03 & Maize-Fallow-Fallow & 4220 & 0.61 & 6 \\
\hline 04 & Groundnut-Fallow-Fallow & 2430 & 0.35 & 9 \\
\hline 05 & Chilli-Jute-Fallow & 1950 & 0.28 & 6 \\
\hline 06 & Tobacco-Vegetab-Vegetab & 1500 & 0.22 & 1 \\
\hline 07 & Wheat-Jute-Fallow & 1460 & 0.21 & 6 \\
\hline 08 & Chilli-Vegetab-Fallow & 1340 & 0.19 & 16 \\
\hline 09 & Maize-Jute-Fallow & 1150 & 0.17 & 3 \\
\hline 10 & Vegetab-Fallow-Fallow & 1150 & 0.17 & 3 \\
\hline 11 & Maize-Vegetab-Fallow & 1120 & 0.16 & 4 \\
\hline 12 & Onion-Vegtab-Vegetab & 1050 & 0.15 & 7 \\
\hline 13 & Onion-Jute-Fallow & 980 & 0.14 & 5 \\
\hline 14 & Potato-Groundnut & 930 & 0.13 & 6 \\
\hline 15 & Millet (cheena)-Fallow-Fallow & 890 & 0.13 & 3 \\
\hline 16 & S.Potato-Jute-Fallow & 770 & 0.11 & 2 \\
\hline 17 & Lentil-Jute-Fallow & 760 & 0.11 & 4 \\
\hline 18 & Vegetab-Jute-Fallow & 730 & 0.10 & 3 \\
\hline 19 & Tobacco-Maize-Vegetab & 600 & 0.09 & 1 \\
\hline 20 & Garlic-Vegetab-Vegetab & 580 & 0.08 & 6 \\
\hline 21 & Chilli-Fallow-Fallow & 530 & 0.08 & 4 \\
\hline 22 & Vegetab-Fallow-Blackgram & 530 & 0.08 & 8 \\
\hline 23 & Maize-Sesame-Fallow & 500 & 0.07 & 1 \\
\hline 24 & Tobacco-Fallow-Fallow & 490 & 0.07 & 2 \\
\hline 25 & Millet (cheena)-Jute-Fallow & 450 & 0.06 & 1 \\
\hline 26 & S.Potato-Fallow-Fallow & 360 & 0.05 & 5 \\
\hline 27 & Fallow-Fallow-Blackgram & 290 & 0.04 & 4 \\
\hline 28 & Garlic-Jute-Fallow & 260 & 0.04 & 4 \\
\hline 29 & Wheat-Ginger/Turmeric & 230 & 0.03 & 1 \\
\hline 30 & Blackgram-Jute-Fallow & 200 & 0.03 & 1 \\
\hline \multirow[t]{2}{*}{$31-49$} & Other 19 patterns (in Table 8) & 1930 & 0.28 & - \\
\hline & Total for exclusive non-rice crop & 44640 & 6.41 & \\
\hline
\end{tabular}

area whereas millet is cultivated in the smallest area. After Maize, wheat is widely cultivated cereal crops under diversified cropping systems in Rangpur region. There were 21 patterns based on maize, which all-together covers 81,130 ha of land (11.65\% of NCA) in the region. Wheat was leading 11 cropping patterns with an area coverage of 26,925 ha $(3.87 \%$ of NCA). In Bangladesh there is a vast market of wheat for human consumption and maize seeds for feed industries. Local production of wheat and maize is extremely insignificant to meet up the demand. The situation is increasing our dependency on import causing a great pressure on foreign currency (BBS, 2014). Loam and sandy-loam soil of the comparative dry area is very suitable for maize cultivation. Wheat cultivation with its better yield in this region is specially favoured by long winter season that is normally unavailable in southern parts of the country. Light textured soil with low waterholding capacity as well as less availability of irrigation water are driving forces that discourage the farmers for modern Boro cultivation. During the harvesting period of wheat the crop is privileged by clear sun-shine and low humidity. All these are the factors for which this area is dominated by maize and wheat cropping systems (FAO, 1988). 
Table 4. Cropping patterns with wheat and maize and other minor cereals in Rangpur region, 2014-15.

\begin{tabular}{|c|c|c|c|c|}
\hline & Cropping pattern & Area (ha) & $\%$ of NCA & Frequency (no. of upazila) \\
\hline 01 & Maize-Fallow-T. Aman & 37630 & 5.40 & 24 \\
\hline 02 & Wheat-Jute-T. Aman & 22660 & 3.25 & 34 \\
\hline 03 & Potato-Maize-T. Aman & 12720 & 1.83 & 22 \\
\hline 04 & Maize-Jute-T. Aman & 9760 & 1.40 & 16 \\
\hline 05 & Tobacco-Maize-T. Aman & 6880 & 0.99 & 9 \\
\hline 06 & Maize-Fallow-Fallow & 4220 & 0.61 & 6 \\
\hline 07 & Vegetab-Maize-T. Aman & 2520 & 0.36 & 6 \\
\hline 08 & Boro-Fallow-Maize & 1500 & 0.22 & 1 \\
\hline 09 & Wheat-Jute-Fallow & 1460 & 0.21 & 6 \\
\hline 10 & Wheat-Fallow-T. Aman & 1260 & 0.18 & 6 \\
\hline 11 & Maize-Jute-Fallow & 1150 & 0.17 & 3 \\
\hline 12 & Maize-Vegetab-Fallow & 1120 & 0.16 & 4 \\
\hline 13 & Maize-Aus-T. Aman & 930 & 0.13 & 3 \\
\hline 14 & Millet (cheena)-Fallow-Fallow & 890 & 0.13 & 3 \\
\hline 15 & Millet (kaon)-Fallow-T. Aman & 800 & 0.11 & 2 \\
\hline 16 & Wheat-Aus-T. Aman & 650 & 0.09 & 10 \\
\hline 17 & Tobacco-Maize-Vegetab & 600 & 0.09 & 1 \\
\hline 18 & Mustard-Maize-T. Aman & 550 & 0.08 & 3 \\
\hline 19 & Maize-Sesame-Fallow & 500 & 0.07 & 1 \\
\hline 20 & Millet (cheena)-Jute-Fallow & 450 & 0.06 & 1 \\
\hline 21 & Wheat-Vegetab-T. Aman & 305 & 0.04 & 2 \\
\hline 22 & Wheat-Ginger/Turmeric & 230 & 0.03 & 1 \\
\hline 23 & Onion-Maize-T. Aman & 220 & 0.03 & 2 \\
\hline 24 & Maize-Boro-T. Aman & 200 & 0.03 & 1 \\
\hline 25 & Potato+Maize-Vegetab-T. Aman & 200 & 0.03 & 1 \\
\hline 26 & Millet (kaon)+Sesame-Fallow & 40 & 0.01 & 1 \\
\hline \multirow[t]{2}{*}{$27-35$} & Other nine patterns (in Table 8) & 710 & 0.10 & - \\
\hline & Total of non-rice cereal crops & 110155 & 15.82 & \\
\hline
\end{tabular}

\section{Vegetables and spices crops}

Sixty-three cropping patterns have been arranged in descending order according to area coverage (Table 5). Potato and other vegeatbles of Rabi, Kharif-I and Kharif-II; spices (chilli, onion, garlic, coriander and black cumin) are included in this list. Total area for vegetables and spices crops in the region is $127,455 \mathrm{ha}$ ( $18.30 \%$ of NCA). The most contributing cropping pattern is Potato-Boro-T. Aman covering $5.16 \%$ of NCA, which is distributed over 22 upazilas. The second one is Potato-Maize-T. Aman covering $1.83 \%$ of NCA. Year-round vegetables here is the most available pattern recorded in 25 upazilas out of 35 . For availability of irrigation water in dry season, supply of modern varieties of various crops, skilled technology transfer system, knowledge on modern crop management practices, high market value of fresh vegetables, good communication and marketing facilities enhanced the extensive production of various types of vegetables in Rangpur region (FAO, 1988). Vegetables like colocasia, okra, amaranthus, brinjal, cucurbits, etc are grown in medium upland adjacent to rice fields during rainy season and potato, sweet gourd, cole crops, leafy vegetables etc are grown during winter season in Tripura (Das et.al., 2015).

\section{Pulses and oil-seed crops}

Forty-three cropping patterns are holding different pulses and oilseed crops (Table 6). Among them mustard is covering the largest area. Nine cropping patterns of mustard alltogether cover 29,210 ha $(4.19 \%$ of NCA).The second largest area is covered by groundnut. There were five cropping patterns for 
Table 5. Cropping patterns with vegetables and spices in Rangpur region, 2014-15.

\begin{tabular}{|c|c|c|c|c|}
\hline & Cropping pattern & Area (ha) & $\%$ of NCA & Frequency (no. of upazila) \\
\hline 01 & Potato-Boro-T. Aman & 35960 & 5.16 & 22 \\
\hline 02 & Potato-Maize-T. Aman & 12720 & 1.83 & 22 \\
\hline 03 & Potato-Jute-T. Aman & 10790 & 1.55 & 24 \\
\hline 04 & Vegetab-Vegetab-Vegetab & 10590 & 1.52 & 25 \\
\hline 05 & Potato-Aus-T. Aman & 6470 & 0.93 & 16 \\
\hline 06 & Vegetab-Vegetab-Fallow & 4670 & 0.67 & 11 \\
\hline 07 & Potato-Fallow-T. Aman & 3850 & 0.55 & 5 \\
\hline 08 & Onion-Jute-T. Aman & 3720 & 0.53 & 20 \\
\hline 09 & Vegetab-Vegetab-T. Aman & 2710 & 0.39 & 12 \\
\hline 10 & Chilli-Fallow-T. Aman & 2660 & 0.38 & 9 \\
\hline 11 & Vegetab-Maize-T. Aman & 2520 & 0.36 & 6 \\
\hline 12 & Potato-Vegetab-T. Aman & 2390 & 0.34 & 9 \\
\hline 13 & Potato-Boro-Fallow & 2000 & 0.29 & 1 \\
\hline 14 & Chilli-Jute-Fallow & 1950 & 0.28 & 6 \\
\hline 15 & Vegetab-Fallow-T. Aman & 1650 & 0.24 & 7 \\
\hline 16 & Chilli-Jute-T. Aman & 1560 & 0.22 & 9 \\
\hline 17 & Vegetab-Boro-T. Aman & 1520 & 0.22 & 4 \\
\hline 18 & Tobacco-Vegetab-Vegetab & 1500 & 0.22 & 1 \\
\hline 19 & Garlic-Jute-T. Aman & 1380 & 0.20 & 16 \\
\hline 20 & Chilli-Vegetab-Fallow & 1340 & 0.19 & 16 \\
\hline 21 & Vegetab-Fallow-Fallow & 1150 & 0.17 & 3 \\
\hline 22 & Maize-Vegetab-Fallow & 1120 & 0.16 & 4 \\
\hline 23 & Onion-Vegtab-Vegetab & 1050 & 0.15 & 7 \\
\hline 24 & Onion-Jute-Fallow & 980 & 0.14 & 5 \\
\hline 25 & Potato-Groundnut & 930 & 0.13 & 6 \\
\hline 26 & Vegetab-Groundnut-T. Aman & 860 & 0.12 & 2 \\
\hline 27 & Vegetab-Jute-Fallow & 730 & 0.10 & 3 \\
\hline 28 & Vegetab-Aus-T. Aman & 660 & 0.09 & 2 \\
\hline 29 & Boro-Vegetab(Float/Norm) & 600 & 0.09 & 1 \\
\hline 30 & Tobacco-Maize-Vegetab & 600 & 0.09 & 1 \\
\hline 31 & Vegetab-Jute-T. Aman & 590 & 0.08 & 6 \\
\hline 32 & Garlic-Vegetab-Vegetab & 580 & 0.08 & 6 \\
\hline 33 & Chilli-Fallow-Fallow & 530 & 0.08 & 4 \\
\hline 34 & Vegetab-Fallow-Blackgram & 530 & 0.08 & 8 \\
\hline 35 & Onion-Aus-T. Aman & 400 & 0.06 & 1 \\
\hline 36 & Wheat-Vegetab-T. Aman & 305 & 0.04 & 2 \\
\hline 37 & Vegetab-Boro-Fallow & 300 & 0.04 & 1 \\
\hline 38 & Chilli-Vegetab-T. Aman & 260 & 0.04 & 4 \\
\hline 39 & Garlic-Fallow-T. Aman & 260 & 0.04 & 5 \\
\hline 40 & Garlic-Jute-Fallow & 260 & 0.04 & 4 \\
\hline 41 & Onion-Fallow-T. Aman & 260 & 0.04 & 3 \\
\hline 42 & Wheat-Ginger/Turmeric & 230 & 0.03 & 1 \\
\hline 43 & Onion-Maize-T. Aman & 220 & 0.03 & 2 \\
\hline 44 & Fallow-Vegetab-T. Aman & 200 & 0.03 & 1 \\
\hline 45 & Potato+Maize-Vegetab-T. Aman & 200 & 0.03 & 1 \\
\hline $46-63$ & Other 18 patterns (in Table 8) & 1700 & 0.24 & - \\
\hline & Total vegetables and spices & 127455 & 18.30 & \\
\hline
\end{tabular}


groundnut, which unitedly has a coverage of 3,460 ha $(0.50 \%$ of NCA). Other pulses and oilseed crops hold a number of cropping patterns, however, with non-significant coverage for each individual. Oil is an essential ingredient of human food and also for feed industries. The country is almost dependent on import for oil. Mustard is a very potential crop that can be grown widely in various parts of the country (BBS, 2014). At present, the lion-share of mustard cultivation is related to the land for double rice. If technology transfer activities are strengthened much more area of the aforesaid category will be possible to make room for the mustard crop (FAO, 1988).

\section{Hazardous crop}

In this investigation, tobacco was found to grow under eight cropping patterns covering 19,120 ha (Table 7) which is equivalent to $2.75 \%$ of total NCA in the region. The major pattern Tobacco-Maize-T. Aman solely cover 6,800 ha that represents one-third of total tobacco area. The most distributed pattern in this region is Tobacco-Fallow-T. Aman that found in 10 upazilas out of 35 . Vegetables, fibre and cereal are grown after tobacco cultivation. Tobacco is one of the major cash crop in Rangpur region. But now-a-day's government and some other organizations are making campaign for not growing tobacco. In consideration of human health and social impact the tobacco crop is discouraged on principle. However, people of the concerned area can not give up the cultivation of tobacco. Famers consider the crop as an insurance of his property. Industry personnel make assurance to purchase their products with price. Moreover, they pay money in advance as production cost. They supply all inputs and technologies for successful production of tobacco. These are privileges of farmers for tobacco cultivation.

\section{Sporadic and distinct cropping patterns}

Tobacco-Vegetables-Vegetables is an extremely location specific cropping pattern which is limited only in Aditmari upazila of Lalmonirhat district with an area of 1,500 ha (Table 7). Potato-Boro-Fallow is another exception, which is practiced in Pirgachha upazila of Rangpur district. This pattern has occupied an area of 2,000 ha (Table 5). The third one is Boro-F-Maize, which is practiced only in Gobindaganj upazila of Gaibandha district with an area coverage of 1,500 ha (Table 4).

\section{Rare cropping patterns}

In the present investigation, 40 cropping patterns have been identified as rare cropping patterns with negligible area coverage and seldom existence (Table 8). These are location specific system and are limited in one to three upazilas of the region. Total area coverage of the 40 patterns is far less than 1\% of NCA. Among them the highest area was allotted for Lentil-Vegetables-Vegetables (190 ha) and it is recorded only in Razibpur upazila of Kurigram district and Pirganj upazila of Rangpur district. The smallest area was recorded for two cropping patterns whose coverage was five hectares for each (Table 8).

\section{Most dominant cropping pattern}

Boro-Fallow- T. Aman was the most dominant cropping pattern in Rangpur region. It covers $53.33 \%$ of NCA in the region and is available in almost all upazilas (Table 9). The highest area under this cropping was recorded 23,200 ha in Sundarganj upazila which represents 6.25\% of the total Boro-Fallow-T. Aman area of the region. In consideration of individual upazila, Palasbari upazila stand $15^{\text {th }}$ position $(11,000$ ha), however, this upazila has allocated highest share and it is $80 \%$ of its NCA for this pattern alone. Razibpur, Chilmari and Kaunia upazila had negligible area coverage for this cropping pattern. In the country-wide compilation of data it was observed that Boro-F-T. Aman was the most dominant cropping pattern in Bangladesh covering 2.31 million ha $(27 \%$ of NCA in the country) with its distribution in 426 upazilas of 63 districts (Nasim et al., 2017).

\section{Second dominant cropping pattern}

The second dominant cropping pattern in Rangpur region is Maize-Fallow-T. Aman . It belongs to $5.40 \%$ of NCA of the region and spread out over 23 upazilas (Table 10). Patgram 
Table 6. Cropping patterns with pulses and oil-seed crops in Rangpur region, 2014-15.

\begin{tabular}{|c|c|c|c|c|}
\hline & Cropping pattern & Area (ha) & $\%$ of NCA & Frequency (no. of upazila) \\
\hline 01 & Mustard-Boro-T. Aman & 22840 & 3.28 & 30 \\
\hline 02 & Mustard-Boro-Fallow & 2650 & 0.38 & 5 \\
\hline 03 & Groundnut-Fallow-Fallow & 2430 & 0.35 & 9 \\
\hline 04 & Mustard-Jute-T. Aman & 2210 & 0.32 & 6 \\
\hline 05 & Potato-Groundnut & 930 & 0.13 & 6 \\
\hline 06 & Vegetab-Groundnut-T. Aman & 860 & 0.12 & 2 \\
\hline 07 & Lentil-Jute-Fallow & 760 & 0.11 & 4 \\
\hline 08 & Boro-Fallow-Blackgram & 700 & 0.10 & 2 \\
\hline 09 & Mustard-Maize-T. Aman & 550 & 0.08 & 3 \\
\hline 10 & Vegetab-Fallow-Blackgram & 530 & 0.08 & 8 \\
\hline 11 & Maize-Sesame-Fallow & 500 & 0.07 & 1 \\
\hline 12 & Groundnut-Fallow-T. Aman & 490 & 0.07 & 2 \\
\hline 13 & Lentil-Jute-T. Aman & 460 & 0.07 & 10 \\
\hline 14 & Lentil-Fallow-T. Aman & 440 & 0.06 & 4 \\
\hline 15 & Groundnut-Jute-T. Aman & 390 & 0.06 & 3 \\
\hline 16 & Mustard-Aus-T. Aman & 350 & 0.05 & 2 \\
\hline 17 & Mustard-Fallow-T. Aman & 350 & 0.05 & 2 \\
\hline 18 & Blackgram-Jute-T. Aman & 320 & 0.05 & 2 \\
\hline 19 & Fallow-Fallow-Blackgram & 290 & 0.04 & 4 \\
\hline 20 & Blackgram-Jute-Fallow & 200 & 0.03 & 1 \\
\hline $21-43$ & Other 23 patterns (in Table 8) & 1260 & 0.18 & - \\
\hline & Total pulses and oil-seeds & 39510 & 5.67 & \\
\hline
\end{tabular}

Table 7. Cropping patterns of hazardous crop in Rangpur region, 2014-15.

\begin{tabular}{llccc}
\hline & Cropping pattern & Area (ha) & \% of NCA & Frequency (no. of upazila) \\
\hline 01 & Tobacco-Maize-T. Aman & 6880 & 0.99 & 9 \\
02 & Tobacco-Aus-T. Aman & 3090 & 0.44 & 9 \\
03 & Tobacco-Jute-T. Aman & 3010 & 0.43 & 9 \\
04 & Tobacco-Boro-T. Aman & 1850 & 0.27 & 3 \\
05 & Tobacco-Fallow-T. Aman & 1700 & 0.24 & 10 \\
06 & Tobacco-Vegetab-Vegetab & 1500 & 0.22 & 1 \\
07 & Tobacco-Maize-Vegetab & 600 & 0.09 & 1 \\
08 & Tobacco-Fallow-Fallow & 490 & 0.07 & 2 \\
\hline & Total & 19120 & 2.75 & \\
\hline
\end{tabular}

upazila of Lalmonirhat district holds the highest area of 10,200 ha followed by Hatibandha upazila of the same district (6,500 ha) under this MaizeFallow-T. Aman cropping pattern. These two upazilas jointly contribute about $45 \%$ share of Maize-Fallow-T. Aman cropping area in the region. Sadullapur and Kishoreganj upazilas are holding the lowest area (below 1\%) of this pattern.

\section{Third dominant cropping pattern}

Potato-Boro-T. Aman cropping pattern holds the third largest area coverage 35,960 ha in Rangpur region. This area is an equivalent to $5.16 \%$ of NCA in the region. Potato is the most cultivated vegetable crop in Rangpur region. This pattern Potato-Boro-T. Aman is distributed over 22 upazilas. Mithapukur upazila of Rangpur district has an area of 6,300 ha for this pattern, which alone stands for $17.52 \%$ of the total area under this pattern in the region (Table 11). In the country-wide compilation of data it was observed that Potato-Boro-T. Aman was the $8^{\text {th }}$ dominant cropping pattern in Bangladesh covering 1.80 lac ha $(2.11 \%$ of NCA in the country) with its distribution in 115 upazilas of 33 districts (Nasim et al., 2017). 
Table 8. Rare cropping patterns covering non-significant areain Rangpur region, 2014-15.

\begin{tabular}{|c|c|c|c|c|c|}
\hline & Cropping pattern & Area (ha) & $\%$ of NCA & Frequency & Upazila \\
\hline 01 & Lentil-Vegetab-Vegetab & 190 & 0.03 & 2 & Razibpur+Pirganj \\
\hline 02 & Wheat-Vegetab-Vegetab & 170 & 0.02 & 1 & Badarganj \\
\hline 03 & Coriander-Fallow-Fallow & 160 & 0.02 & 3 & Rowmari+Domar+Pirganj \\
\hline 04 & Potato-Chilli-Fallow & 160 & 0.02 & 1 & Domar \\
\hline 05 & Coriander-Jute-Fallow & 150 & 0.02 & 2 & Fulchhari+Saghata \\
\hline 06 & Lentil-Sesame-Fallow & 150 & 0.02 & 1 & Kurigram sadar \\
\hline 07 & Mustard-Jute-Fallow & 150 & 0.02 & 1 & Lalmonirhat sadar \\
\hline 08 & Potato-Jute-Fallow & 150 & 0.02 & 1 & Nageswari \\
\hline 09 & Maize-Mungbean-Vegetab & 120 & 0.02 & 1 & Kurigram sadar \\
\hline 10 & S.Potato-Fallow-T. Aman & 120 & 0.02 & 3 & Kurigramsadar+Domar+Kishoreganj \\
\hline 11 & Groundnut- Aus-Fallow & 100 & 0.01 & 1 & Nageswari \\
\hline 12 & Mustard-Aus-Fallow & 100 & 0.01 & 1 & Pirganj \\
\hline 13 & Vegetab-Jute-Vegetab & 100 & 0.01 & 1 & Kishoreganj \\
\hline 14 & Coriander-Vegetab-Fallow & 90 & 0.01 & 3 & Dimla+Kishoreganj+Saidpur \\
\hline 15 & Potato-Maize-Fallow & 90 & 0.01 & 2 & Rajarhat+Saidpur \\
\hline 16 & Grasspea-Jute-T. Aman & 80 & 0.01 & 2 & Rajarhat+Sundarganj \\
\hline 17 & Maize-Vegetab-T. Aman & 80 & 0.01 & 2 & Phulbari+Kaliganj \\
\hline 18 & Wheat-Maize-T. Aman & 80 & 0.01 & 1 & Kurigram sadar \\
\hline 19 & Potato-Mungbean-T. Aman & 70 & 0.01 & 3 & Kaliganj+Dimla+Badarganj \\
\hline 20 & Coriander-Fallow-T. Aman & 60 & 0.01 & 1 & Jhaldhaka \\
\hline 21 & Onion-Maize-Fallow & 60 & 0.01 & 1 & Lalmonirhat sadar \\
\hline 22 & Wheat-Mungbean-T. Aman & 60 & 0.01 & 3 & Sundarganj+Domar+Kishoreganj \\
\hline 23 & Grasspea-Fallow-T. Aman & 50 & 0.01 & 1 & Fulchhari \\
\hline 24 & Groundnut-Sesame-Fallow & 50 & 0.01 & 1 & Sundarganj \\
\hline 25 & Blackgram-Aus-T. Aman & 40 & 0.01 & 1 & Aditmari \\
\hline 26 & Fallow-Sesame-T. Aman & 40 & 0.01 & 1 & Rajarhat \\
\hline 27 & Millet(kaon)+Sesame-Fallow & 40 & 0.01 & 1 & Sundarganj \\
\hline 28 & S.Potato-Vegetab-Fallow & 40 & 0.01 & 2 & Dimla+Mithapukur \\
\hline 29 & Lentil-Vegetab-T. Aman & 30 & 0.00 & 1 & Phulbari \\
\hline 30 & Wht-Sesame-B.gram(Orchard) & 30 & 0.00 & 1 & Badarganj \\
\hline 31 & Blackcumin-Jute-Fallow & 20 & 0.00 & 1 & Rowmari \\
\hline 32 & Sesame-Fallow-T. Aman & 20 & 0.00 & 1 & Aditmari \\
\hline 33 & Wheat-Aus-Fallow & 20 & 0.00 & 1 & Bhurungamari \\
\hline 34 & Grasspea-Fallow-Fallow & 10 & 0.00 & 1 & Gaibandha sadar \\
\hline 35 & Lentil-Aus-T. Aman & 10 & 0.00 & 1 & Phulbari \\
\hline 36 & Mustard-Boro-Jute-T. Aman & 10 & 0.00 & 1 & Rowmari \\
\hline 37 & Potato-Groundnut-T. Aman & 10 & 0.00 & 1 & Kishoreganj \\
\hline 38 & Potato-Sesame-T. Aman & 10 & 0.00 & 1 & Mithapukur \\
\hline 39 & Mungbean-Fallow-T. Aman & 5 & 0.00 & 1 & Nageswari \\
\hline \multirow[t]{2}{*}{40} & Mungbean-Jute-T. Aman & 5 & 0.00 & 1 & Nageswari \\
\hline & Total & 2930 & 0.40 & & \\
\hline
\end{tabular}


Table 9. Distribution of the most dominant Boro-Fallow-T. Aman cropping patterns in Rangpur region, $2014-15$.

\begin{tabular}{|c|c|c|c|c|}
\hline & Upazila & Area (ha) & $\%$ of upazila NCA & $\%$ of the pattern in region \\
\hline 01 & Sundarganj & 23200 & 74.91 & 6.25 \\
\hline 02 & Mithapukur & 22500 & 50.53 & 6.06 \\
\hline 03 & Gobindaganj & 17800 & 48.89 & 4.79 \\
\hline 04 & Nageswari & 17400 & 62.46 & 4.69 \\
\hline 05 & Ulipur & 17200 & 70.90 & 4.63 \\
\hline 06 & Nilphamri sadar & 16000 & 52.91 & 4.31 \\
\hline 07 & Gaibandha sadar & 14600 & 74.76 & 3.93 \\
\hline 08 & Pirganj & 14000 & 42.89 & 3.77 \\
\hline 09 & Domar & 13100 & 65.30 & 3.53 \\
\hline 10 & Kaliganj & 12500 & 64.20 & 3.37 \\
\hline 11 & Sadullapur & 12300 & 71.59 & 3.31 \\
\hline 12 & Badarganj & 12000 & 53.81 & 3.23 \\
\hline 13 & Jaldhaka & 12000 & 50.65 & 3.23 \\
\hline 14 & Saghata & 11070 & 65.50 & 2.98 \\
\hline 15 & Palasbari & 11000 & 77.19 & 2.96 \\
\hline 16 & Dimla & 10700 & 45.65 & 2.88 \\
\hline 17 & Bhurungamari & 10000 & 57.41 & 2.69 \\
\hline 18 & Rajarhat & 9300 & 68.94 & 2.50 \\
\hline 19 & Kurigram sadar & 9300 & 48.69 & 2.50 \\
\hline 20 & Phulbari & 9200 & 73.31 & 2.48 \\
\hline 21 & Lal. sadar & 9200 & 47.67 & 2.48 \\
\hline 22 & Hatibandha & 8800 & 38.21 & 2.37 \\
\hline 23 & Aditmari & 8400 & 52.08 & 2.26 \\
\hline 24 & Pirgachha & 8000 & 40.34 & 2.15 \\
\hline 25 & Kishoreganj & 7000 & 46.30 & 1.88 \\
\hline 26 & Gangachara & 7000 & 33.59 & 1.88 \\
\hline 27 & Rangpur sadar & 6800 & 58.67 & 1.83 \\
\hline 28 & Fulchhari & 6700 & 41.56 & 1.80 \\
\hline 29 & Saidpur & 6500 & 71.74 & 1.75 \\
\hline 30 & Taraganj & 6000 & 52.08 & 1.62 \\
\hline 31 & Patgram & 5700 & 27.26 & 1.53 \\
\hline 32 & Rowmari & 5100 & 36.45 & 1.37 \\
\hline 33 & Kaunia & 5000 & 41.67 & 1.35 \\
\hline 34 & Razibpur & 3000 & 34.32 & 0.81 \\
\hline \multirow[t]{2}{*}{35} & Chilmari & 3000 & 25.10 & 0.81 \\
\hline & Rangpur region & 371370 & 53.33 & 100.00 \\
\hline
\end{tabular}

\section{Fourth dominant cropping pattern}

Single Boro cropping pattern holds the fourth largest area coverage 28,320 ha in Rangpur region. This area is an equivalent to $4.07 \%$ of NCA in the region. This pattern Boro-Fallow-Fallow is distributed over 28 upazilas. Pirgachha has an area of 4,900 ha for single Boro which stands for $17.3 \%$ of the total area under this pattern in the region (Table 12). This pattern is frequent and concurrently experienced by early flash flood in April and cold injury at reproductive stage. Diversified cropping pattern may be resort for the farmer as a coping strategy with flood related risk (Mandal and Bezbaruah, 2013) but scope of diversification is limited due to environmental and climatic condition (FAO, 1988). In the country-wide compilation of data it was observed that the single Boro was the $2^{\text {nd }}$ dominant cropping pattern in Bangladesh covering 1.14 million ha $(13 \%$ of NCA in the country) with its distribution in 342 upazilas of 59 districts (Nasim et al., 2017). 
Table 10. Distribution of the $2^{\text {nd }}$ dominant Maize-Fallow-T. Aman cropping pattern in Rangpur region, $2014-15$.

\begin{tabular}{|c|c|c|c|c|}
\hline & Upazila & Area (ha) & $\%$ of upazila NCA & $\%$ of the pattern in region \\
\hline 01 & Patgram & 10200 & 49.04 & 27.11 \\
\hline 02 & Hatibandha & 6500 & 28.51 & 17.27 \\
\hline 03 & Dimla & 5000 & 21.93 & 13.29 \\
\hline 04 & Kaliganj & 2250 & 11.66 & 5.98 \\
\hline 05 & Pirganj & 2900 & 9.15 & 7.71 \\
\hline 06 & Mithapukur & 3600 & 8.20 & 9.57 \\
\hline 07 & Jaldhaka & 1350 & 5.83 & 3.59 \\
\hline 08 & Gobindaganj & 1200 & 3.55 & 3.19 \\
\hline 09 & Nilphamari sadar & 1000 & 3.32 & 2.66 \\
\hline 10 & Badarganj & 750 & 3.50 & 1.99 \\
\hline 11 & Lalmonirhat sadar & 600 & 3.19 & 1.59 \\
\hline 12 & Palasbari & 400 & 2.91 & 1.06 \\
\hline 13 & Domar & 370 & 1.87 & 0.98 \\
\hline 14 & Pirgachha & 300 & 1.56 & 0.80 \\
\hline 15 & Nageswari & 200 & 0.72 & 0.53 \\
\hline 16 & Rajarhat & 200 & 1.49 & 0.53 \\
\hline 17 & Kaunia & 200 & 1.69 & 0.53 \\
\hline 18 & Sundarganj & 150 & 0.49 & 0.40 \\
\hline 19 & Ulipur & 150 & 0.62 & 0.40 \\
\hline 20 & Kurigram sadar & 100 & 0.54 & 0.27 \\
\hline 21 & Saaidpur & 90 & 1.01 & 0.24 \\
\hline 22 & Sadullapur & 60 & 0.36 & 0.16 \\
\hline \multirow[t]{2}{*}{23} & Kishoreganj & 50 & 0.34 & 0.13 \\
\hline & Rangpur region & 37630 & 5.40 & 100.00 \\
\hline
\end{tabular}

Table 11. Distribution of the $3^{\text {rd }}$ dominant Potato-Boro-T. Aman cropping pattern in Rangpur region, $2014-15$.

\begin{tabular}{|c|c|c|c|c|}
\hline & Upazila & Area (ha) & $\%$ of upazila NCA & $\%$ of the pattern in region \\
\hline 01 & Mithapukur & 6300 & 14.35 & 17.52 \\
\hline 02 & Gobindaganj & 4700 & 13.91 & 13.07 \\
\hline 03 & Nilphamari sadar & 4000 & 13.29 & 11.12 \\
\hline 04 & Pirganj & 3000 & 15.63 & 8.34 \\
\hline 05 & Kishoreganj & 2100 & 14.38 & 5.84 \\
\hline 06 & Kaunia & 1700 & 14.41 & 4.73 \\
\hline 07 & Badarganj & 1500 & 7.01 & 4.17 \\
\hline 08 & Gangachara & 1500 & 7.25 & 4.17 \\
\hline 09 & Pirgachha & 1200 & 3.79 & 3.34 \\
\hline 10 & Jaldhaka & 1170 & 5.05 & 3.25 \\
\hline 11 & Sundarganj & 1100 & 3.58 & 3.06 \\
\hline 12 & Sadullapur & 1000 & 6.02 & 2.78 \\
\hline 13 & Dimla & 1000 & 4.39 & 2.78 \\
\hline 14 & Domar & 1000 & 5.06 & 2.78 \\
\hline 15 & Saidpur & 800 & 8.99 & 2.22 \\
\hline 16 & Palasbari & 800 & 5.82 & 2.22 \\
\hline 17 & Kurigram sadar & 780 & 4.19 & 2.17 \\
\hline 18 & Rajarhat & 700 & 5.22 & 1.95 \\
\hline 19 & Lalmonirhat sadar & 550 & 2.93 & 1.53 \\
\hline 20 & Phulbari & 500 & 4.07 & 1.39 \\
\hline 21 & Saghata & 400 & 2.38 & 1.11 \\
\hline \multirow[t]{2}{*}{22} & Patgram & 160 & 0.77 & 0.44 \\
\hline & Rangpur region & 35960 & 5.16 & 100.00 \\
\hline
\end{tabular}


Fifth dominant cropping pattern

Fifth dominant cropping pattern MustardBoro-T. Aman had been covering 22,840 ha representing $3.28 \%$ share of NCA in Rangpur region (Table 13). This pattern is distributed over 30 upazilas where Gobindaganj ranked in top position. This upazila has 3,600 ha area for this pattern which is only $10.65 \%$ of upazila NCA. In consideration of area coverage Rowmari upazila stands in second position, however, it has allotted the biggest share ie $18.12 \%$ of upazila NCA. In the country-wide compilation of data, it was observed that Mustard-Boro-T. Aman was the $6^{\text {th }}$ dominant cropping pattern in Bangladesh covering 1.85 lac ha $(2.16 \%$ of NCA in the country) with its distribution in 203 upazilas of 51 districts (Nasim et al., 2017).
Crop diversity and cropping intensity

Higher number of available crops under cultivation in an area dictates its higher diversity. Number of cropping patterns is also a gross indicator of crop diversity. A total of 134 cropping patterns were identified in the whole area of Rangpur region under this investigation. The highest number of cropping patterns was identified 31 in Badarganj of Rangpur and Dimla upazila of Nilphamari respectively (Table 14). The lowest number of cropping patterns was identified 10 in Razibpur followed by 13 in Saghata and 14 in Rangpur sadar, Kaunia and Gobindaganj. Higher number of cropping patterns is generally related to higher level of diversity indices. The upazilas having lower number of cropping patterns were related to either drought or flood or both. The

Table 12. Distribution of the $4^{\text {th }}$ dominant Boro-F-F cropping pattern in Rangpur region, 2014-15.

\begin{tabular}{|c|c|c|c|c|}
\hline & Upazila & Area (ha) & $\%$ of upazila NCA & $\%$ of the pattern in region \\
\hline 01 & Pirgachha & 4900 & 15.46 & 17.30 \\
\hline 02 & Nageswari & 4000 & 14.44 & 14.12 \\
\hline 03 & Gaibandha & 2400 & 12.31 & 8.47 \\
\hline 04 & Chilmari & 1700 & 14.29 & 6.00 \\
\hline 05 & Gobindaganj & 1600 & 4.73 & 5.65 \\
\hline 06 & Mithapukur & 1500 & 3.42 & 5.30 \\
\hline 07 & Razibpur & 1450 & 17.06 & 5.12 \\
\hline 08 & Bhurungamari & 1200 & 6.98 & 4.24 \\
\hline 09 & Nilphamari sadar & 1200 & 3.99 & 4.24 \\
\hline 10 & Fulchhari & 1100 & 6.83 & 3.88 \\
\hline 11 & Saghata & 1000 & 5.95 & 3.53 \\
\hline 12 & Aditmari & 1000 & 6.31 & 3.53 \\
\hline 13 & Ulipur & 750 & 3.10 & 2.65 \\
\hline 14 & Kurigram sadar & 750 & 4.03 & 2.65 \\
\hline 15 & Rajarhat & 700 & 5.22 & 2.47 \\
\hline 16 & Kaunia & 600 & 5.08 & 2.12 \\
\hline 17 & Sundarganj & 600 & 1.95 & 2.12 \\
\hline 18 & Lalmonirhat & 500 & 2.66 & 1.77 \\
\hline 19 & Kaliganj & 250 & 1.30 & 0.88 \\
\hline 20 & Badarganj & 200 & 0.93 & 0.71 \\
\hline 21 & Kishoreganj & 200 & 1.37 & 0.71 \\
\hline 22 & Patgram & 200 & 0.96 & 0.71 \\
\hline 23 & Hatibandha & 150 & 0.66 & 0.53 \\
\hline 24 & Rangpur sadar & 120 & 1.05 & 0.42 \\
\hline 25 & Gangachara & 100 & 0.48 & 0.35 \\
\hline 26 & Taraganj & 50 & 0.46 & 0.18 \\
\hline 27 & Dimla & 50 & 0.22 & 0.18 \\
\hline \multirow[t]{2}{*}{28} & Phulbari & 50 & 0.41 & 0.18 \\
\hline & Rangpur region & 28320 & 4.07 & 100.00 \\
\hline
\end{tabular}


Table 13. Distribution of the $5^{\text {th }}$ dominant Mustard-Boro-T. Aman cropping pattern, 2014-15.

\begin{tabular}{|c|c|c|c|c|}
\hline & Upazila & Area (ha) & $\%$ of upazila NCA & $\%$ of the pattern in region \\
\hline 01 & Gobindaganj & 3600 & 10.65 & 15.76 \\
\hline 02 & Rowmari & 2500 & 18.12 & 10.95 \\
\hline 03 & Badarganj & 2000 & 9.35 & 8.76 \\
\hline 04 & Kurigram sadar & 1500 & 8.06 & 6.57 \\
\hline 05 & Nageswari & 1500 & 5.42 & 6.57 \\
\hline 06 & Nilphamari sadar & 1500 & 4.98 & 6.57 \\
\hline 07 & Ulipr & 1200 & 4.96 & 5.25 \\
\hline 08 & Fulchhari & 1100 & 6.83 & 4.82 \\
\hline 09 & Sadullapur & 700 & 4.22 & 3.06 \\
\hline 10 & Phulbari & 700 & 5.69 & 3.06 \\
\hline 11 & Saghata & 500 & 2.98 & 2.19 \\
\hline 12 & Bhurungamari & 500 & 2.91 & 2.19 \\
\hline 13 & Mithapukur & 500 & 1.14 & 2.19 \\
\hline 14 & Sundarganj & 450 & 1.47 & 1.97 \\
\hline 15 & Hatibandha & 450 & 1.97 & 1.97 \\
\hline 16 & Jaldhaka & 450 & 1.94 & 1.97 \\
\hline 17 & Pirgachha & 400 & 2.08 & 1.75 \\
\hline 18 & Pirganj & 350 & 1.10 & 1.53 \\
\hline 19 & Kaliganj & 340 & 1.76 & 1.49 \\
\hline 20 & Palasbari & 300 & 2.18 & 1.31 \\
\hline 21 & Lalmonirhat sadar & 300 & 1.60 & 1.31 \\
\hline 22 & Patgram & 300 & 1.44 & 1.31 \\
\hline 23 & Dimla & 300 & 1.32 & 1.31 \\
\hline 24 & Kishoreganj & 300 & 2.05 & 1.31 \\
\hline 25 & Kaunia & 300 & 2.54 & 1.31 \\
\hline 26 & Domar & 200 & 1.01 & 0.88 \\
\hline 27 & Rangpur sadar & 200 & 1.75 & 0.88 \\
\hline 28 & Taraganj & 200 & 1.85 & 0.88 \\
\hline 29 & Rajarhat & 100 & 0.75 & 0.44 \\
\hline \multirow[t]{2}{*}{30} & Saidpur & 100 & 1.12 & 0.44 \\
\hline & Rangpur region & 22840 & 3.28 & 100.00 \\
\hline
\end{tabular}

lowest diversity index for cropping pattern was recorded 0.281 in Sundarganj followed by 0.527 in Gobindaganj. The highest value of diversity index for cropping pattern was found 0.991 in Rajibpur upazila that was followed by 0.989 in Chilmari upazila. The lowest CDI was reported 0.651 in Sundarganj followed by 0.745 in Pirganj. The highest value of CDI was observed 0.991 in Razibpur followed by 0.989 in Chilmari upazila. The range of cropping intensity values was recorded $190-255 \%$. The maximum value was for Gangachara upazila of Rangpur district and minimum for Gaibandha sadar upazila. As a whole the CDI of Rangpur region was calculated 0.871 and the average cropping intensity at regional level was $219 \%$. In a simultaneous study, the investigators identified 316 cropping patterns for whole Bangladesh; where the CDI value was 0.952 at national level and the national average of cropping intensity was 200\% (Nasim et al., 2017). Diversified cropping pattern may enabled the farmers compulsion of extracting the maximum possible utilization of land in the flood free period (Mandal and Bezbaruah, 2013). Singh and Sidhu (2006) reported that a number of crops like sun hemp, cluster beans and sorghum had almost disappeared and there is reduced varietal diversification in rice and wheat. Crop diversification index of wheat-rice system has decreased from 0.75 in 1975-76 to 0.58 in 2006-07 in Punjab though diversification 
Table 14. Crop diversity and cropping intensity in Rangpur region, 2014-15.

\begin{tabular}{|c|c|c|c|c|c|c|}
\hline & Upazila & $\begin{array}{l}\text { No. of identified } \\
\text { pattern }\end{array}$ & No. of crop & $\begin{array}{l}\text { Diversity index for } \\
\text { cropping pattern }\end{array}$ & $\begin{array}{l}\text { Crop diversity } \\
\text { index (CDI) }\end{array}$ & C.I. (\%) \\
\hline 01 & Rangpur & 14 & 11 & 0.935 & 0.968 & 223 \\
\hline 02 & Gangachara & 26 & 13 & 0.913 & 0.954 & 255 \\
\hline 03 & Kaunia & 14 & 12 & 0.958 & 0.978 & 239 \\
\hline 04 & Pirgachha & 20 & 17 & 0.721 & 0.876 & 225 \\
\hline 05 & Pirganj & 29 & 15 & 0.685 & 0.745 & 203 \\
\hline 06 & Badarganj & 31 & 14 & 0.799 & 0.902 & 225 \\
\hline 07 & Mithapukur & 23 & 12 & 0.788 & 0.872 & 231 \\
\hline 08 & Taraganj & 18 & 11 & 0.874 & 0.902 & 220 \\
\hline 09 & Gaibandha sadar & 16 & 15 & 0.710 & 0.860 & 190 \\
\hline 10 & Palasbari & 18 & 13 & 0.839 & 0.921 & 210 \\
\hline 11 & Gobindaganj & 14 & 12 & 0.527 & 0.772 & 221 \\
\hline 12 & Saghata & 13 & 16 & 0.833 & 0.918 & 218 \\
\hline 13 & Fulchhari & 21 & 17 & 0.932 & 0.967 & 200 \\
\hline 14 & Sundarganj & 26 & 18 & 0.281 & 0.651 & 208 \\
\hline 15 & Sadullapur & 18 & 12 & 0.798 & 0.901 & 215 \\
\hline 16 & Kurigram & 28 & 19 & 0.778 & 0.823 & 227 \\
\hline 17 & Ulipur & 20 & 17 & 0.601 & 0.804 & 210 \\
\hline 18 & Chilmari & 18 & 16 & 0.978 & 0.989 & 191 \\
\hline 19 & Rowmari & 24 & 15 & 0.756 & 0.829 & 240 \\
\hline 20 & Razibpur & 10 & 14 & 0.982 & 0.991 & 206 \\
\hline 21 & Bhurungamari & 18 & 13 & 0.855 & 0.929 & 218 \\
\hline 22 & Nageswari & 25 & 17 & 0.678 & 0.874 & 200 \\
\hline 23 & Phulbari & 18 & 12 & 0.772 & 0.845 & 219 \\
\hline 24 & Rajarhat & 23 & 17 & 0.852 & 0.935 & 211 \\
\hline 25 & Nilphamari & 19 & 13 & 0.630 & 0.819 & 230 \\
\hline 26 & Saidpur & 20 & 12 & 0.943 & 0.972 & 214 \\
\hline 27 & Domar & 25 & 16 & 0.725 & 0.836 & 222 \\
\hline 28 & Dimla & 31 & 14 & 0.701 & 0.835 & 214 \\
\hline 29 & Jaldhaka & 19 & 11 & 0.915 & 0.913 & 223 \\
\hline 30 & Kishoreganj & 28 & 14 & 0.919 & 0.960 & 240 \\
\hline 31 & Lalmonirhat & 25 & 17 & 0.698 & 0.865 & 230 \\
\hline 32 & Aditmari & 16 & 11 & 0.795 & 0.924 & 230 \\
\hline 33 & Kaliganj & 20 & 14 & 0.674 & 0.872 & 237 \\
\hline 34 & Hatibandha & 20 & 12 & 0.914 & 0.918 & 220 \\
\hline \multirow[t]{2}{*}{35} & Patgram & 17 & 13 & 0.815 & 0.909 & 220 \\
\hline & Rangpur region & 134 & 31 & 0.694 & 0.871 & 219 \\
\hline
\end{tabular}

forces pests to continuously relocate and recolonize their preferred host plants from year to year (Tscharntke et al., 2005, 2007).

\section{CONCLUSION}

Boro-Fallow-T. Aman, Maize-Fallow-T. Aman , Potato-Boro-T. Aman and Single Boro were the dominant cropping patterns in the region. The area under pulses and oil-seed crops was much lower, which is a challenge to food and nutritional security for the people of the Rangpur region. Based on the findings of the study, the following recommendations were made.

- Initiative has to be taken to increase productivity of exclusive rice based cropping pattern along with recommended crop management packages. 
- Effort might be given so that a portion of double-rice area could be brought under Potato-Boro-T. Aman and/or MustardBoro-T. Aman cropping systems.

- In the single Boro area suitable vegetables might be grown on floating bed system in wet season.

- For sustainable food and nutritional security the area under pulses and oil seed crops should be escalated

- The upazilas having unique or exceptional cropping patterns with large area coverage might be studied in-depth to extrapolate the similar environments.

- Scope might be explored for the establishment of agro-food industry on the basis of potato crop.

\section{REFERENCES}

Agrawal, D J and A H Kassam. 1976. The importance of multiple cropping in increasing world food supplies. A special publication No. 27, American Society of Agronomy, Madison, Wisconsin. pp. 2-3.

BBS (Bangladesh Bureau of Statistics). 2014. Statistical Yearbook of Bangladesh. Statistics Division, Ministry of Planning, Government of the People's Republic of Bangladesh.

Das, Anup, G I Ramkrushna, GS Yadav, J Layek, C Debnath, B U Choudhury, K P Mohaptara, S V Ngachan and S Das. 2015. Capturing traditional practices of rice based farming systems and identifying interventions for resource conservation and food security in Tripura, India. Applied Ecology and Environmental Sciences. 3(4): 100-107.

FAO, 1988. Land Resources Appraisal of Bangladesh for Agricultural Development- Report 2: Agroecological regions of Bangladesh. Food and Agriculture Organization of the United Nations, Rome, Italy, 570p.

Kshirsagar, K G, S Pandey and M R Bellon. 1997. Farmers' perception, varietal characteristics and technology adoption: the case of rainfed village in eastern India. Discussion paper 5/97. Social Sciences Division, International Rice Research Institute. Los Baňos, Laguna, Philippines.

Mandal, R and M P Bezbaruah. 2013. Diversification of cropping pattern: its determinants and role in flood affected agriculture of Assam Plains. Indian J. Agric. Econ. 68(2): 169-181.

Muttaleb, M A, S M Shahidullah, M Nasim and A Saha. 2017. Cropping systems and land use in Sylhet region. Bangladesh Rice J. 21(2): 273-288.

Nasim, M, S M Shahidullah, A Saha, M A Muttaleb, T L Aditya, M A Ali and M S Kabir. 2017. Distribution of Crops and Cropping Patterns in Bangladesh. Bangladesh Rice J. 21(2): 1-55.

Neena, D. 1998. Interstate variation in cropping pattern in India. Indian J. Regi. Sci. 30(2): 57-69.

Rashid, M H, A H Khan and M MAlam. 2005. Cropping systems dynamics in greater Khustia. J. Bangladesh Agril. Univ. 3(2): 213-238.

Shahidullah, S M, M Nasim, M K Quais and ASaha. 2017. Diversity of Cropping Systems in Chittagong Region. Bangladesh Rice J. 21(2): 109-122.

Shriar, A J. 2000. Agricultural intensity and its measurement in frontier regions.Agroforestry Systems.49(3): 301-318.

Tscharntke, T, R Bommarco, Y Clough, T O Crist, D Klein, T A Rand, J M Tylianakis, S vanNouhuys, and S Vidal. 2007. Conservation biological control and enemy diversity on a landscape scale. Biol. Control. 43: 294-309.

Tscharntke, T, A M Klein, A Kruess, I S Dewenter, and C Thies. 2005. Landscape perspectives on agricultural intensification and biodiversity-ecosystem service management. Ecol. Lett. 8: 857-874. 
Appendix 1. List of cropping patterns in Rangpur region, 2014-15.

\begin{tabular}{|c|c|c|c|c|c|}
\hline & Cropping pattern & Area (ha) & & Cropping pattern & Area (ha) \\
\hline 01 & Boro-Fallow-T. Aman & 371370 & 48 & Potato-Groundnut & 930 \\
\hline 02 & Maize-Fallow-T. Aman & 37630 & 49 & Millet(cheena)-Fallow-Fallow & 890 \\
\hline 03 & Potato-Boro-T. Aman & 35960 & 50 & Vegetab-Groundnut-T. Aman & 860 \\
\hline 04 & Boro-Fallow-Fallow & 28320 & 51 & Millet(kaon)-F-T. Aman & 800 \\
\hline 05 & Mustard-Boro-T. Aman & 22840 & 52 & S.Potato-Jute-Fallow & 770 \\
\hline 06 & Wheat-Jute-T. Aman & 22660 & 53 & Lentil-Jute-Fallow & 760 \\
\hline 07 & Potato-Maize-T. Aman & 12720 & 54 & Vegetab-Jute-Fallow & 730 \\
\hline 08 & Potato-Jute-T. Aman & 10790 & 55 & Boro-Fallow-Blackgram & 700 \\
\hline 09 & Vegetab-Vegetab-Vegetab & 10590 & 56 & Vegetab-Aus-T. Aman & 660 \\
\hline 10 & Maize-Jute-T. Aman & 9760 & 57 & Wheat-Aus-T. Aman & 650 \\
\hline 11 & Tobacco-Maize-T. Aman & 6880 & 58 & Boro-Vegetab(Float/Norm) & 600 \\
\hline 12 & Potato-Aus-T. Aman & 6470 & 59 & Tobacco-Maize-Vegetab & 600 \\
\hline 13 & Boro-Aus-T. Aman & 5640 & 60 & Vegetab-Jute-T. Aman & 590 \\
\hline 14 & Vegetab-Vegetab-Fallow & 4670 & 61 & Garlic-Vegetab-Vegetab & 580 \\
\hline 15 & Maize-Fallow-Fallow & 4220 & 62 & Mustard-Maize-T. Aman & 550 \\
\hline 16 & Potato-Fallow-T. Aman & 3850 & 63 & Chilli-Fallow-Fallow & 530 \\
\hline 17 & Onion-Jute-T. Aman & 3720 & 64 & Vegetab-Fallow-Blackgram & 530 \\
\hline 18 & Tobacco-Aus-T. Aman & 3090 & 65 & Maize-Sesame-Fallow & 500 \\
\hline 19 & Tobacco-Jute-T. Aman & 3010 & 66 & Groundnut-Fallow-T. Aman & 490 \\
\hline 20 & Vegetab-Vegetab-T. Aman & 2710 & 67 & Tobacco-Fallow-Fallow & 490 \\
\hline 21 & Chilli-Fallow-T. Aman & 2660 & 68 & Boro-Sesbania-T. Aman & 480 \\
\hline 22 & Mustard-Boro-Fallow & 2650 & 69 & Lentil-Jute-T. Aman & 460 \\
\hline 23 & Vegetab-Maize-T. Aman & 2520 & 70 & Millet(cheena)-Jute-Fallow & 450 \\
\hline 24 & Groundnut-Fallow-Fallow & 2430 & 71 & Lentil-Fallow-T. Aman & 440 \\
\hline 25 & Potato-Vegetab-T. Aman & 2390 & 72 & Onion-Aus-T. Aman & 400 \\
\hline 26 & Mustard-Jute-T. Aman & 2210 & 73 & Groundnut-Jute-T. Aman & 390 \\
\hline 27 & Boro-Jute-T. Aman & 2080 & 74 & S.Potato-Fallow-Fallow & 360 \\
\hline 28 & Fallow-Jute-T. Aman & 2030 & 75 & Fallow-Fallow-T. Aman & 350 \\
\hline 29 & Potato-Boro-Fallow & 2000 & 76 & Mustard-Aus-T. Aman & 350 \\
\hline 30 & Chilli-Jute-Fallow & 1950 & 77 & Mustard-Fallow-T. Aman & 350 \\
\hline 31 & Tobacco-Boro-T. Aman & 1850 & 78 & S.Potato-Jute-T. Aman & 350 \\
\hline 32 & Tobacco-Fallow-T. Aman & 1700 & 79 & Blackgram-Jute-T. Aman & 320 \\
\hline 33 & Vegetab-Fallow-T. Aman & 1650 & 80 & Wheat-Vegetab-T. Aman & 305 \\
\hline 34 & Chilli-Jute-T. Aman & 1560 & 81 & Boro-Jute-Fallow & 300 \\
\hline 35 & Vegetab-Boro-T. Aman & 1520 & 82 & Boro-Sesbania-Fallow & 300 \\
\hline 36 & Boro-Fallow-Maize & 1500 & 83 & Vegetab-Boro-Fallow & 300 \\
\hline 37 & Tobacco-Vegetab-Vegetab & 1500 & 84 & Fallow-Fallow-Blackgram & 290 \\
\hline 38 & Wheat-Jute-Fallow & 1460 & 85 & Chilli-Vegetab-T. Aman & 260 \\
\hline 39 & Garlic-Jute-T. Aman & 1380 & 86 & Garlic-Fallow-T. Aman & 260 \\
\hline 40 & Chilli-Vegetab-Fallow & 1340 & 87 & Garlic-Jute-Fallow & 260 \\
\hline 41 & Wheat-Fallow-T. Aman & 1260 & 88 & Onion-Fallow-T. Aman & 260 \\
\hline 42 & Maize-Jute-Fallow & 1150 & 89 & Wheat-Ginger/Turmeric & 230 \\
\hline 43 & Vegetab-Fallow-Fallow & 1150 & 90 & Onion-Maize-T. Aman & 220 \\
\hline 44 & Maize-Vegetab-Fallow & 1120 & 91 & Blackgram-Jute-Fallow & 200 \\
\hline 45 & Onion-Vegtab-Vegetab & 1050 & 92 & Fallow-Vegetab-T. Aman & 200 \\
\hline 46 & Onion-Jute-Fallow & 980 & 93 & Maize-Boro-T. Aman & 200 \\
\hline \multirow[t]{2}{*}{47} & Maize-Aus-T. Aman & 930 & 94 & Potato+Maize-Vegetab-T.Aman & 200 \\
\hline & & & $95-134$ & Other 40 patterns (Table 8) & 2930 \\
\hline
\end{tabular}


